\title{
Mosquito vector abundance immediately before and after Tropical Storms Alma and Arthur, northern Belize, 2008
}

\author{
Meredith G. Morrow, ${ }^{1}$ Richard N. Johnson, ${ }^{1}$ \\ Jorge Polanco, ${ }^{2}$ and David M. Claborn ${ }^{3}$
}

Suggested citation Morrow MG, Johnson RN, Polanco J, Claborn DM. Mosquito vector abundance immediately before and after Tropical Storms Alma and Arthur, northern Belize, 2008. Rev Panam Salud Publica. 2010; 28(1):19-24.

\begin{abstract}
Objective. To monitor adult mosquito abundance in northern Belize before/after the first tropical storm of the wet season to estimate the time required for development/recovery of potential vector populations; determine which species predominate post-storm; and compare the effectiveness of two types of mosquito traps-octenol-baited Mosquito Magnets ${ }^{\circledR}$ and U.S. Centers for Disease Control and Prevention (CDC) light traps (with/without octenol).

Methods. Field experiments were conducted in Orange Walk Town, Belize, 21 May to 3 June 2008. Incidence rate ratios and exact binomial 95\% confidence intervals were reported and trap-nights calculated to compare species abundance pre-and post-storm as well as traptype effectiveness.

Results. Twice as many species and three times more Anopheles spp. were trapped prestorm versus post-storm. However, greater numbers of Aedes taeniorhynchus and Culex (Culex) spp. were trapped post-storm. Mosquito Magnets ${ }^{\circledR}$ were consistently more effective than the CDC traps, obtaining twice as many Anopheles spp. and four times as many culicine species as the octenol-baited version (which collected 14 times more mosquitoes overall and 3.5 times more culicine species than the unbaited version). The unbaited CDC trap did not trap any Anopheles spp. during the study period.

Conclusions. Results indicated octenol is an effective attractant for An. crucians in northern Belize; malaria risk in Belize declines immediately post-storm (i.e., mosquito abundance drops); and arboviral risk associated with the rapid increase in culicine mosquitoes post-storm may represent a greater public health threat than malaria (although further research and active disease surveillance is necessary to validate this hypothesis).
\end{abstract}

Key words Insect vectors; mosquito control; vector control; malaria; tropical storm; Belize.

Tropical storms and their effects on vector mosquito population dynamics are

\footnotetext{
1 Department of Preventive Medicine and Biometrics, Uniformed Services University of the Health Sciences (USUHS), Bethesda, Maryland, United States of America. Send correspondence to: Meredith G. Morrow, meredith.morrow@gmail.com

2 Ministry of Health, Belmopan, Belize.

3 Master of Public Health Program, Missouri State University, Springfield, Missouri, United States of America.
}

important factors in disease control and therefore should be considered in public health preparedness and disaster response. Data generated by studies of mosquito population dynamics in areas that receive significant rainfall during storm seasons can be used to estimate which species will predominate after tropical weather events and how quickly potential vector populations may develop and recover (1). These estimates can be useful to disaster response planners who must decide what disease control measures should be implemented and when they should begin (2-4).

This study attempted to record vector species abundance in northern Belize immediately before and after Tropical Storms Alma and Arthur, which occurred simultaneously at the end of the 2008 Belizean dry season. Tropical Storm Alma began on 27 May 2008 as an area of low 
pressure that strengthened into a tropical depression off the coast of Nicaragua. It was designated as the first tropical storm of the season on 29 May 2008 and reached peak winds of $104.6 \mathrm{~km} / \mathrm{h}$ just before making landfall on the northwestern coast of Nicaragua near León $(5,6)$. Forming at $86.5^{\circ} \mathrm{W}$, Alma developed further east than any other Pacific tropical cyclone on record and was also the first tropical storm to make landfall along the Pacific coast of Central America since $1949(5,7)$. Heavy rainfall across Central America (including Belize) caused flash flooding and landslides in Costa Rica and Nicaragua and left 42000 people without power $(6,7)$. Damage was estimated at \$33 million USD (7).

On 30 May 2008, Alma emerged into the Gulf of Honduras and fused with a tropical wave off the coast of Belize that became Tropical Storm Arthur one day before the official start of the 2008 Atlantic hurricane season (5). Tropical Storm Arthur was the first Atlantic tropical storm to form during the month of May since 1981 (5). It made landfall on the Yucatan Peninsula on 31 May 2008 and remained a tropical storm over land for nearly 24 hours before weakening to a tropical depression $(5,8)$. The rainfall from Arthur-approximately $25.4 \mathrm{~cm}$ in Belize over 36 hours-compounded the effects of flooding caused by Tropical Storm Alma (8). This heavy rainfall caused rivers in both southern and northern Belize to overflow, damaging bridges and highways and forcing evacuations in Orange Walk District in the north as well as parts of Corozal, Mexico (8). Flash flooding reportedly killed nine people in Belize and affected 100000 more. Damage was estimated at $\$ 78$ million USD (8).

The authors of the current study, who were working in the area where the early tropical storms occurred, designed and implemented the current research to take advantage of the opportunity to compare the mosquito vector abundance immediately before and after the first heavy rainfall of the wet season. This type of data may be useful in estimating the effect of tropical storms on local vector populations and subsequent changes in disease risks. A secondary goal of the study was to compare the efficacy of two types of mosquito traps in northern Belize: the commercially produced Mosquito Magnet $^{\circledR}$ (Woodstream Corp., Lititz, PA, USA) and the U.S. Centers for Disease
Control and Prevention (CDC) light trap (with and without octenol attractant).

\section{MATERIALS AND METHODS}

\section{Mosquito abundances pre- and post-tropical storms}

Field experiments were conducted on approximately 607 ha of cattle pasture bordered by mixed brush, marsh, and sugarcane habitat in a malarious area in northern Belize (Orange Walk Town). The first trial was conducted with four of the Mosquito Magnet ${ }^{\circledR}$ traps, which were used to monitor mosquito activity from 21 May to 3 June. As per manufacturer instructions, the traps were sheltered from rainfall-in this case inside two-person tents utilized by the U.S. military (National Stock Number 834001026 6096). The distance from the tent opening to the Mosquito Magnet ${ }^{\circledR}$ was approximately $1 \mathrm{~m}$. Although the tents had been treated with insecticides as part of another study, statistical analysis indicated the treatments were not effective (i.e., the trap catches from the treated tents did not differ from those of the control tent $[P=$ 0.161]). The four Mosquito Magnet ${ }^{\circledR}$ traps were run nightly, 12 hours per sampling day (1800 to $0600 \mathrm{~h}$ ), four nights before the first storm of the wet season (25-28 May) and four nights after (31 May-3 June), yielding 16 trap-nights (number of traps run [4] $\times$ number of nights [4] = 16) for each of the two comparison time periods (pre- and post-storm).

Each of the four Mosquito Magnet ${ }^{\circledR}$ traps utilized a 3.8-liter tank of $60 \%$ propane and $40 \%$ butane to produce heat and carbon dioxide (a by-product of the combustion process). The propane/ butane mix was chosen because it was widely available in Central America and consistent with Mosquito Magnet ${ }^{\circledR}$ manufacturer's instructions. Each Mosquito Magnet ${ }^{\circledR}$ was baited with the $1600-\mathrm{mg}$ octenol cartridge included with each trap and operated according to manufacturer's instructions.

The tents were spaced $20 \mathrm{~m}$ apart and arranged in a line parallel to and approximately $100 \mathrm{~m}$ from a local marsh (a mosquito breeding site). The sides of the tents facing the marsh $\left(60^{\circ} \mathrm{NNE}\right)$ were left open. The backs of the tents were staked to the ground but left unbuttoned to prevent overheating of the trap and avoid the repellent effect of excessive heat.
Octenol-baited Mosquito Magnets ${ }^{\circledR}$ versus octenol-baited CDC trap. Along with the tents used to house the four octenol-baited Mosquito Magnet ${ }^{\circledR}$ traps, an additional tent was set up to house one CDC light trap, which was baited with the same 1600 -mg octenol cartridge supplied with each Mosquito Magnet ${ }^{\circledR}$ and run for the same daily sampling period (1800 to $0600 \mathrm{~h}$ ). No carbon dioxide was used. To evaluate the effectiveness of the two types of traps, Mosquito Magnet $^{\circledR}$ trap data from 20-28 May (4 traps $\times$ 8 nights or 32 trap-nights) were compared with data from the single baited CDC light trap run from 20-27 May (1 trap $\times 7$ nights or 7 trap-nights).

Octenol-baited CDC light trap housed inside tent versus unbaited CDC light traps outside tent. Two unbaited CDC light traps were also run, outside the tents. Data from these traps were compared with data from the single baited CDC light trap housed inside the tent to evaluate the effectiveness of octenol as an attractant. The two unbaited CDC light traps were run for five nights (28 May and 31 May-3 June), and the single octenol-baited CDC light trap was run for 10 nights (23-28 May, 31 May, and 1-3 June), generating a total of 10 trapnights for each ( 2 traps $\times 5$ nights and 1 trap $\times 10$ nights respectively). Both traps were run for the same daily sampling period (1800 to $0600 \mathrm{~h}$ ). As in the previous trial, no carbon dioxide was used.

All mosquitoes from the daily trap catches were counted and identified to species using a dichotomous key $(9,10)$. Voucher specimens were later deposited in the collections of the U.S. Army's Walter Reed Biosystematics Unit (WRBU) at the Smithsonian Institution National Museum of Natural History (NMNH).

\section{Statistical analysis}

The abundances of mosquitoes per trap-night were calculated to determine any notable differences pre- and poststorm (comparing the Mosquito Magnet ${ }^{\circledR}$ trap data before and after the rainfall) and to assess the effectiveness of the octenol attractant (comparing the data from the octenol-baited CDC trap inside the tent with data from the unbaited CDC traps outside the tent). Incidence rate ratios and exact binomial 95\% confidence intervals (CIs) were calculated using Stata Statisti- 
cal Software version 10.0 (StataCorp LP, College Station, TX, USA) (11).

\section{RESULTS}

\section{Mosquito abundances pre- and post-tropical storms}

There was a significant difference in the abundance of mosquitoes trapped by the octenol-baited Mosquito Magnets ${ }^{\circledR}$ run immediately before the storm versus those run immediately after the storm for all species except for Anopheles vestitipennis (Dyar and Knab, 1906), Psorophora ferox (Von Humboldt, 1819), and Ps. albipes (Theobald, 1907). The fact that the trap rates for these latter three species did not differ is most likely due to the low numbers of specimens obtained (Table 1). While the total number of culicine species collected by the traps did not change pre- versus post-storm, the species composition was altered, with increases in the number of Aedes taeniorhynchus (Wiedemann, 1958) and Culex (Culex) spp. post-storm. All Culex spp. were identified down to the subgenus Culex. As explained by J. Pecor (NMNH/WRBU, personal communication, 5 July 2007), the $C x$. (Cx.) spp. could not be identified down to any of the 11 species found within this subgenus in Belize due to the lack of male specimens. Conversely, the total number of Anopheles spp. was three times higher before the storm compared to afterward. The total number of species caught post-storm de-

TABLE 1. Number of mosquitoes collected in four octenol-baited Mosquito Magnet ${ }^{\circledR}$ traps run inside tents for four nights before the first tropical storm of the wet season (25-28 May) and four nights after (31 May-3 June), Orange Walk Town, Belize, 2008

\begin{tabular}{lrrrrrrr}
\hline \multicolumn{1}{c}{ Species } & $\begin{array}{c}\text { Pre- } \\
\text { storm } \\
\text { (total) }\end{array}$ & $\begin{array}{c}\text { Post- } \\
\text { storm } \\
\text { (total) }\end{array}$ & $\begin{array}{c}\text { Pre-storm } \\
\text { (per trap- } \\
\text { night) }\end{array}$ & $\begin{array}{c}\text { Post-storm } \\
\text { (per trap- } \\
\text { night) }\end{array}$ & IRR $^{\mathrm{b}}$ & $95 \% \mathrm{Cl}^{\mathrm{c}}$ & $P$ \\
\hline Anopheles spp. & 722 & 223 & 45.1 & 13.9 & 3.2 & $(2.8,3.8)$ & $<0.001$ \\
An. albimanus & 128 & 30 & 8 & 1.9 & 4.2 & $(2.8,6.6)$ & $<0.001$ \\
An. crucians & 587 & 183 & 36.7 & 11.4 & 3.2 & $(2.7,3.8)$ & $<0.001$ \\
An. vestitipennis & 7 & 10 & 0.4 & 0.6 & 0.6 & $(0.2,2.0)$ & 0.48 \\
Culicine spp. & 415 & 391 & 25.9 & 24.4 & 1.1 & $(0.9,1.2)$ & 0.40 \\
Coquillettidia nigricans & 264 & 42 & 16.5 & 2.6 & 6.3 & $(4.5,8.9)$ & $<0.001$ \\
Mansonia titillans & 146 & 204 & 9.1 & 12.8 & 0.7 & $(0.6,0.9)$ & 0.02 \\
Culex spp. & 5 & 56 & 0.3 & 3.5 & 0.1 & $(0.03,0.2)$ & $<0.001$ \\
Aedes taeniorhynchus & 0 & 86 & 0 & 5.4 & $\ldots$ & $(0,0.04)$ & $<0.001$ \\
Psorophora ferox & 0 & 0 & 0 & 0 & $\ldots$ & $\ldots$ & 1.00 \\
Ps. albipes & 0 & 3 & 0 & 0.2 & $\ldots$ & $(0,2.4)$ & 0.13 \\
Total & 1137 & 614 & 71.1 & 38.4 & 1.9 & $(1.7,2.0)$ & $<0.001$ \\
\hline
\end{tabular}

${ }^{a}$ Number of traps run $(4) \times$ number of nights $(4)=16$ trap-nights per comparison period (pre- and post-storm).

b Internal rate of return.

${ }^{c}$ Confidence interval.

d Insufficient data for calculation. creased by half (pre-storm total = 1 137; post-storm total $=614)$.

An. crucians (Wiedemann, 1949) was the most abundant species before the storm, followed by Coquillettidia nigricans (Coquillet, 1904) and Mansonia titillans (Walker, 1848). No Ae. taeniorhynchus and only five Culex spp. specimens were trapped immediately before the storm. The species trapped most often poststorm was Ma. titillans, followed by $A n$. crucians. Ae. taeniorhynchus and Culex spp. were trapped more often immediately following the storm.

Octenol-baited Mosquito Magnets ${ }^{\circledR}$ versus octenol-baited CDC trap. There was a significant difference in trap rates between the octenol-baited Mosquito Magnets ${ }^{\circledR}$ and CDC light trap housed in tents for all species except Ps. ferox and Ps. albipes. The small number of trapped specimens for these latter two species prevented reliable statistical analysis.

The octenol-baited Mosquito Magnets ${ }^{\circledR}$ produced an average of 54.7 mosquitoes per trap-night (total trapped = 1750) whereas the octenol-baited CDC light trap caught an average of 20.4 mosquitoes per trap-night (total trapped = 143) (Table 2). However, the bulk of the trap rate from the CDC light trap was due to an abnormally high yield of $A n$. crucians on a single night that was most likely due to the presence of livestock in the vicinity during that period (the CDC trap was closer to the livestock than the Mosquito Magnets ${ }^{\circledR}$ and was therefore

\section{s.}

\section{.} Culex spp., Ae. taeniorhynchus, Ps. ferox, and Ps. albipes), primarily due to the low trap rates of the latter group of species. However, the octenol-baited CDC trap (run inside the tent) was more effective overall than the unbaited traps (run outside the tent), obtaining 19.3 total mosquitoes per trap-night (total trapped = 193) versus only 1.4 total mosquitoes per trap-night (total trapped $=14$ ) for the unbaited traps and thus almost 14 times more mosquitoes overall (and 3.5 times more culicine species). An. crucians was the species trapped most often in the baited CDC trap. The unbaited trap failed to collect any specimens from this species throughout the study period. 
TABLE 2. Number of mosquitoes collected in four octenol-baited Mosquito Magnet $^{\circledR}$ traps and one CDCa light trap run inside tents for eight nights (20-28 May) and seven nights (20-27 May) respectively, Orange Walk Town, Belize, 2008

\begin{tabular}{|c|c|c|c|c|c|c|c|}
\hline Species & $\begin{array}{c}\text { Mosquito } \\
\text { Magnet }^{\circledR} \\
\text { traps } \\
\text { (total) }\end{array}$ & $\begin{array}{l}\mathrm{CDC} \\
\text { light } \\
\text { trap } \\
\text { (total) }\end{array}$ & $\begin{array}{c}\text { Mosquito } \\
\text { Magnet }^{\circledR} \\
\text { traps } \\
\text { (per trap- } \\
\text { night) }^{\mathrm{b}}\end{array}$ & $\begin{array}{c}\text { CDC } \\
\text { light trap } \\
\text { (per trap- } \\
\text { night) }\end{array}$ & $I_{R} R^{d}$ & $95 \% \mathrm{Cl}^{\mathrm{e}}$ & $P$ \\
\hline Anopheles spp. & 945 & 100 & 29.5 & 14.3 & 2.1 & $(1.7,2.6)$ & $<0.001$ \\
\hline An. albimanus & 158 & 0 & 4.9 & 0 & $\ldots{ }^{f}$ & $(9.3, \ldots)$ & $<0.001$ \\
\hline An. crucians & 770 & 100 & 24.1 & $14.3^{9}$ & 1.7 & $(1.4,2.1)$ & $<0.001$ \\
\hline An. vestitipennis & 17 & 0 & 0.5 & 0 & & $(0.9, \ldots)$ & 0.03 \\
\hline Culicine spp. & 805 & 43 & 25.2 & 6.1 & 4.1 & $(3.0,5.7)$ & $<0.001$ \\
\hline Coquillettidia nigricans & 306 & 14 & 9.6 & 2.0 & 4.8 & $(2.8,8.9)$ & $<0.001$ \\
\hline Mansonia titillans & 350 & 26 & 10.9 & 3.7 & 2.9 & $(2.9,2.0)$ & $<0.001$ \\
\hline Culex spp. & 61 & 2 & 1.9 & 0.3 & 6.3 & $(1.8,56.3)$ & $<0.001$ \\
\hline Aedes taeniorhynchus & 86 & 0 & 2.7 & 0 & $\ldots$ & $(5.0, \ldots)$ & $<0.001$ \\
\hline Psorophora ferox & 0 & 1 & 0 & 0.1 & $\ldots$ & $(0,8.5)$ & 0.18 \\
\hline Ps. albipes & 3 & 0 & 0.1 & 0 & $\ldots$ & $(0.09, \ldots)$ & 0.55 \\
\hline Total & 1750 & 143 & 54.7 & 20.4 & 2.7 & $(2.2,3.2)$ & $<0.001$ \\
\hline \multicolumn{8}{|c|}{ Excluding abnormally high $\mathrm{CDC}$ trap rate recorded for one night of sampling } \\
\hline An. crucian & 770 & 26 & 24.1 & 4.3 & 5.6 & $(3.8,8.5)$ & $<0.001$ \\
\hline All species & 1750 & 69 & 54.7 & 11.5 & 4.8 & $(3.7,6.1)$ & $<0.001$ \\
\hline
\end{tabular}

${ }^{a}$ Centers for Disease Control and Prevention (USA).

${ }^{\mathrm{b}}$ Number of traps run (4) $x$ number of nights $(8)=32$ trap-nights.

c Number of traps run (1) $x$ number of nights $(7)=7$ trap-nights.

dInternal rate of return.

${ }^{\text {e}}$ Confidence interval.

${ }^{f}$ Insufficient data for calculation.

Includes abnormally high trap rate recorded for one night (possibly attributable to the presence of livestock near the CDC trap during that period).

TABLE 3. Number of mosquitoes collected in one octenol-baited CDCa light trap run inside a tent for ten nights (23-28 May, 31 May, 1-3 June) and two unbaited CDC light traps run outside tents for five nights (28 May and 31 May-3 June), Orange Walk Town, Belize, 2008

\begin{tabular}{|c|c|c|c|c|c|c|c|}
\hline Species & $\begin{array}{l}\text { Octenol- } \\
\text { baited } \\
\text { trap } \\
\text { (total) }\end{array}$ & $\begin{array}{l}\text { Unbaited } \\
\text { traps } \\
\text { (total) }\end{array}$ & $\begin{array}{l}\text { Octenol- } \\
\text { baited } \\
\text { trap } \\
\text { (per trap- } \\
\text { night) }{ }^{b}\end{array}$ & $\begin{array}{l}\text { Unbaited } \\
\text { traps } \\
\text { (per trap- } \\
\text { night) }\end{array}$ & $\mathrm{IRR}^{\mathrm{d}}$ & $95 \% \mathrm{Cl}^{\mathrm{e}}$ & $P$ \\
\hline Anopheles spp. & 143 & 0 & 14.3 & 0 & $N A^{f}$ & $(38.3, \ldots 9)$ & $<0.001$ \\
\hline An. albimanus & 1 & 0 & 0.1 & 0 & NA & $(0.03, \ldots)$ & 0.50 \\
\hline An. crucians & 142 & 0 & 14.2 & 0 & NA & $(38.0, \ldots)$ & $<0.001$ \\
\hline An. vestitipennis & 0 & 0 & 0 & 0 & NA & & 1.00 \\
\hline Culicine spp. & 50 & 14 & 5.0 & 1.4 & 3.6 & $(1.9,7.0)$ & $<0.001$ \\
\hline Coquillettidia nigricans & 18 & 11 & 1.8 & 1.1 & 1.6 & $(0.7,3.8)$ & 0.20 \\
\hline Mansonia titillans & 29 & 3 & 2.9 & 0.3 & 9.6 & $(3.0,49.6)$ & $<0.001$ \\
\hline Culex spp. & 2 & 0 & 0.2 & 0 & NA & $(0.2, \ldots)$ & 0.25 \\
\hline Aedes taeniorhynchus & 0 & 0 & 0 & 0 & NA & $\ldots$ & 1.00 \\
\hline Psorophora ferox & 1 & 0 & 0.1 & 0 & NA & $(0.03, \ldots)$ & 0.50 \\
\hline Ps. albipes & 0 & 0 & 0 & 0 & NA & & 1.00 \\
\hline Total & 193 & 14 & 19.3 & 1.4 & 13.8 & $(8.0,25.7)$ & $<0.001$ \\
\hline
\end{tabular}

${ }^{\mathrm{a}}$ Centers for Disease Control and Prevention (USA).

${ }^{b}$ Number of traps run $(1) \times$ number of nights $(10)=10$ trap-nights.

${ }^{c}$ Number of traps run (2) $\times$ number of nights $(5)=10$ trap-nights.

${ }^{d}$ Internal rate of return.

${ }^{\text {e}}$ Confidence interval.

${ }^{\dagger}$ Not applicable (IRRs were not estimable for species that were not collected in the unbaited traps).

Insufficient data for calculation.

\section{DISCUSSION}

Because many mosquito-borne diseases are found in regions of the world at risk for hurricanes and tropical storms, understanding the effects of such events on local vector-borne disease epidemiology is important for directing appropriate public health responses (12). Caillouët et al. (2008) showed that after
Hurricane Katrina there was a sharp increase in the number of reported cases of neuroinvasive West Nile virus disease in hurricane-affected regions (13). They also found a $>2$-fold increase in incidence of neuroinvasive West Nile virus disease in hurricane-affected areas for 2006 versus previous years (13). Many of these cases occurred among construction workers and other cleanup crew, underscoring the need to provide adequate shelter and mosquito control for disaster relief volunteers and workers as well as residents of affected areas in the days and weeks that follow the storm $(12,14,15)$. During the post-storm cleanup of Hurricane Andrew, repair and cleanup crews were exposed to high densities of mosquitoes, which increased the potential for mosquito-borne disease transmission as well as bacterial infections from mosquito bites. Like the post-storm species composition in Belize found in the current study, the most common species collected post-Hurricane Andrew in both Florida and Louisiana were mainly Culicine spp. (15). It should be noted, however, that the studies cited above do not reliably link increased mosquito abundance with increased risk of disease because the increased disease incidence could have been due to increased human exposure to vectors rather than increased vector numbers.

In the current study, an increase in the variety of culicine species was noted as soon as four days post-storm. However, a drastic drop in Anopheles spp. was also noted post-storm, which may have implications for malaria prevention during storm seasons (16). In northern Belize, malaria is mesoendemic and moderately unstable, with seasonal epidemic exacerbations showing a fairly close correlation with alterations in rainfall (17). As documented in this study, habitat damage from tropical weather events can disturb Anopheles spp. populations enough to temporarily reduce their abundance and thus their role in malaria transmission (18). This finding suggests that public health interventions to prevent malaria immediately after a storm may not be as important as previously assumed (19), although this hypothesis is somewhat controversial in the literature because malaria transmission is not always directly correlated with number of mosquitoes or amount of rainfall (e.g., very low numbers of mosquitoes can also produce significant disease transmis- 
sion) (20,21)). Once the Anopheles vectors are reestablished in the environment, however, the increased rainfall provides a suitable breeding habitat, thus increasing the chance for a possible outbreak, as was seen after Hurricane Flora swept across the southern peninsula of Haiti (17). Conversely, this re-stabilization period can take many weeks to months, most likely depending on the strength of the storm and associated wind speed (17, 19). For this reason, natural disasters do not usually cause an immediate increase in vector-borne diseases. In areas that are heavily damaged, however, vector control may be inappropriately delayed during the most paramount of timesimmediately after the storm-when most residents of the affected areas are still living in evacuation areas $(4,22)$.

The current study found that Culex spp. in Belize are able to increase rapidly following a storm and should potentially be regarded as a possible vector of interest immediately following heavy rainfall, especially at the end of the dry season. If hurricanes strike early in transmission season, there could be a late increase in risk after vector and host populations are reestablished. Culex spp. are able to transmit a number of pathogens to humans (e.g., West Nile virus and Venezuelan equine encephalitis virus) and therefore may require immediate control measures after heavy rainfall in northern Belize. It should be noted, however, that although these results indicate the abundance of certain vector species can increase rapidly after heavy rainfall, further studies and increased surveillance of diseases associated with these vector species are needed to ascertain whether or not this increase in species abundance leads to a direct increase in disease risk.

As mentioned above, based on the research results, the authors of the current study concluded that 1) the Mosquito Magnet ${ }^{\circledR}$ was more effective at trapping all species of mosquitoes (Anopheles spp. and culicines) than the octenol-baited CDC light trap, and 2) octenol is a reliable attractant for An. crucians in northern Belize (based on the observation that the unbaited CDC light traps failed to collect any specimens from this species whereas the octenol-baited CDC trap attracted a high number of them). These findings may prove useful for public health planners attempting to set up field surveillance programs after tropical weather has devastated an area.

\section{Limitations}

This study had several limitations. For example, in the trap comparison studies, there was an uneven number of replicates (due to the unpredictable nature of storms). If this type of study were attempted in the future, comparison of an equal number of trap-nights and trial nights would be preferable. In the preand post-storm study, the main weakness was the shortened temporal scope. A longer collection time (both pre- and post-storm) would improve the analysis and allow for consideration of the varying life cycles of potential vectors found in northern Belize. Although the current results indicating a parallel decrease in density of mosquitoes during the first 48 hours after storms are supported by studies conducted in 2000-2001 on the effect of tropical storms on adult mosquito abundance in Calcutta, India, it would be useful to determine how long this decrease in total species lasts and what factors play a role in rebuilding affected mosquito populations (23).

In addition, future studies examining mosquito populations before and after several tropical storms and hurricanes would further clarify how mosquito abundance is altered by these weather events and how it varies on an annual basis. Comparing mosquito populations during two or more different storm years could prove useful in determining how other climatic, temporal, and environmental factors facilitate breeding in certain species post-storm (21). After Tropical Storm Doreen hit California in 1977, Gordon et al. hypothesized that many breeding cycles are obligatory in nature and are modified primarily by temperature rather than precipitation (21). Comparing these results to those of the current study, it should be noted that the rains caused by Tropical Storm Doreen were not thought to have created favorable breeding habitats due to lack of vegetation and larval activity, whereas the current research site had profound vegetation in its water sources. In any case, it is clear that mosquito abundance and composition can vary tremendously in a region affected by tropical storms. This underscores the importance of species abundance research pre- and post-storms to facilitate and improve public health planning for devastated areas. It also further justifies the need for active disease surveillance during these time frames to identify any increases in certain species that may lead to a subsequent increase in disease risk or transmission.

Acknowledgments. The authors thank Cara Olsen for her help in the statistical analyses and the anonymous reviewers whose comments helped improve the manuscript.

Financial support. Funding for this work was provided by Uniformed Services University of the Health Sciences, Bethesda, Maryland, under grant number GS87K3.

Disclaimer. The opinions, interpretations, conclusions, and recommendations contained herein are those of the authors and do not reflect official views or policy of the Uniformed Services University of the Health Sciences or the U.S. Department of Defense.

\section{REFERENCES}

1. Juliano SA. Population dynamics. J Am Mosq Control Assoc. 2007;23(2 Suppl):265-75.

2. Fillinger $U$, Sombroek $H$, Majambere $S$, van Loon E, Takken W, Lindsay SW. Identifying the most productive breeding sites for malaria mosquitoes in The Gambia. Malar J. 2009;8:62, doi:10.1186/1475-2875-8-62.

3. Grieco JP, Vogtsberger RC, Achee NL, Vanzie E, Andre RG, Roberts DR, et al. Evaluation of habitat management strategies for the reduction of malaria vectors in northern Belize. J Vector Ecol. 2005;30(2):235-43.

4. Watson JT, Gayer M, Connolly MA. Epidemics after natural disasters. Emerg Infect Dis. 2007;13(1):1-5.

5. National Oceanic and Atmospheric Administration, National Climatic Data Center (US) [homepage on the Internet]. Washington:
NOAA; 2008 [cited 2009 Sept 18]. State of the climate-hurricanes \& tropical storms; [about 2 screens]. Available from: http://www. ncdc.noaa.gov/sotc/?report=tropicalcyclones\&year $=2008 \&$ month $=5$.

6. International Federation of Red Cross and Red Crescent Societies. Costa Rica and Nicaragua: Tropical Storm Alma. DREF operation no. MDR43003 final report. Geneva: 
IFRC; 2009 [cited 2009 Sept 18]. Available from: http://www.ifrc.org/docs/appeals/ rpts08/MDR43003dfr.pdf.

7. United Nations Office for the Coordination of Humanitarian Affairs. Weekly note on emergencies: Latin America \& the Caribbean. No. 59, 23 Jun 2008. New York: OCHA; 2008 [cited 2009 Sept 18]. Available from: http:// www.reliefweb.int/rw/R-Files2008. nsf/fb9 a3459e0c5a152c1257205004f1c3e/e9b2c9a5ca d313a0c1257461006e7fe0 / \$FILE / Full. Report.pdf.

8. International Federation of Red Cross and Red Crescent Societies. Belize: Tropical Storm Arthur. DREF operation no. MDRBZ001 final report. Geneva: IFRC; 2008 [cited 2009 Sept 18]. Available from: http://www2.reliefweb. int/rw/rwb.nsf/db900sid/EDIS-7MKR8Z? OpenDocument\&query $=\% 20$ Tropical $\% 20$ Sto rm\%20Arthur\&emid=TC-2008-000077-CRI.

9. Clark-Gil S, Darsie RF Jr. The mosquitoes of Guatemala: their identification, distribution and binomics with keys to adult females and larvae in English and Spanish. Mosq Syst. 1983;15(3):151-284.

10. Pecor JE, Harbach RE, Peyton EL, Roberts DR, Rejmankova E, Manguin S, et al. Mosquito studies in Belize, Central America: records, taxonomic notes, and a checklist of species. J Am Mosq Control Assoc. 2002;18(4): $241-76$.
11. Rothman KJ. Modern epidemiology. Boston: Little Brown; 1986. p. 166.

12. Diaz JH. Global climate changes, natural disasters, and travel health risks. J Travel Med. 2006;13(6):361-72.

13. Caillouët KA, Michaels SR, Xiong X, Foppa I, Wesson DM. Increase in West Nile virus neuroinvasive disease after Hurricane Katrina. Emerg Infect Dis. 2008;14(5):804-7.

14. Swygard H, Stafford RE. Effects on health of volunteers deployed during a disaster. Am Surg. 2009;75(9):747-52; discussion 752-3.

15. Centers for Disease Control and Prevention (US). Emergency mosquito control associated with Hurricane Andrew-Florida and Louisiana, 1992. MMWR Morb Mortal Wkly Rep. 1993;42(13):240-2.

16. Achee NL, Korves CT, Bangs MJ, Rejmankova E, Lege M, Curtin D, et al. Plasmodium vivax polymorphs and Plasmodium falciparum circumsporozoite proteins in Anopheles (Diptera: Culicidae) from Belize, Central America. J Vector Ecol. 2000;25(2): 203-11.

17. Mason J and Cavalie P. Malaria epidemic in Haiti following a hurricane. Am J Trop Med Hyg. 1965;14(4):533-9.

18. Achee NL, Grieco JP, Rejmankova E, Andre RG, Vanzie E, Polanco J, et al. Biting patterns and seasonal densities of Anopheles mosquitoes in the Cayo District, Belize, Central
America with emphasis on Anopheles darlingi. J Vector Ecol. 2006;31(1):45-57.

19. Lehman JA, Hinckley AF, Kniss KL, Nasci RS, Smith TL, Campbell GL, et al. Effect of Hurricane Katrina on arboviral disease transmission. Emerg Infect Dis. 2007;13(8):1273-5.

20. Warrell DA, Gilles HM. Essential malariology. 4th ed. London: Arnold International 2002. p. 59

21. Gordon EW, Smith TA, Ortiz J, Moisse E. The effects of Tropical Storm Doreen on mosquito populations in Imperial Valley. Proceedings and Papers of the 46th Annual Conference of the California Mosquito and Vector Control Association; 1978 Jan 29-Feb 1; Yosemite, California, USA. Visalia (CA): CMVCA Press; 1978. p. 55-7.

22. Nasci RS, Moore CG. Vector-borne disease surveillance and natural disasters. Emerg Infect Dis. 1998;4(2):333-4.

23. Pramanik M, Raut SK. Impact of kalbaishakhi storms on adult mosquito populations in Kolkata (Calcutta), India. Acta Trop. 2003;85 (1):93-5.

Manuscript received on 15 January 2010. Revised version accepted for publication on 9 June 2010.
RESUMEN

\section{Abundancia de mosquitos vectores inmediatamente antes y después de las tormentas tropicales Alma y Arthur, norte de Belice, 2008}

Palabras clave
Objetivo. Comprobar la abundancia de mosquitos adultos en el norte de Belice antes y después de la primera tormenta tropical de la temporada de lluvias, para calcular la cantidad de tiempo que necesitan las poblaciones de vectores potenciales para desarrollarse y recuperarse; determinar cuáles son las especies que predominan después de la tormenta; y comparar la eficacia de dos tipos de trampas de mosquitos: las que utilizan cebos de octenol (Mosquito Magnets ${ }^{\circledR}$ ) y las trampas de luz con y sin octenol de los Centros para el Control y la Prevención de Enfermedades de los Estados Unidos (CDC). Métodos. Se llevaron a cabo pruebas de campo en Orange Walk Town, Belice, desde el 21 de mayo hasta el 3 de junio del 2008. Se registraron las razones de las tasas de incidencia y los intervalos de confianza binomiales exactos de $95 \%$ y se evaluaron las trampas nocturnas para comparar la abundancia de las especies y la eficacia del tipo de trampa antes y después de una tormenta.

Resultados. Antes de la tormenta, se atrapó el doble de las especies de mosquitos y el triple de Anopheles spp. en comparación con el período que siguió a la tormenta. Sin embargo, el número de Aedes taeniorhynchus y Culex (Culex) spp. atrapados fue mayor después de la tormenta. Las trampas Mosquito Magnets ${ }^{\circledR}$ demostraron uniformemente ser más eficaces que las trampas de los CDC, ya que el número de Anopheles spp. capturados fue dos veces mayor que el de la trampa con cebo de octenol y el número de especies de culícidos fue cuatro veces mayor. En general, el número de mosquitos capturados por la trampa con octenol fue 14 veces mayor que el de la trampa sin octenol y el número de especies de culícidos fue 3,5 veces mayor. La trampa sin cebo de los CDC no capturó ningún Anopheles spp. durante el período de estudio.

Conclusiones. Los resultados demostraron que el octenol es un producto eficaz para atraer a la especie Anopheles crucians en el norte de Belice. En este país, el riesgo de malaria disminuye inmediatamente después de las tormentas (es decir, disminuye la abundancia de mosquitos); y el riesgo de contraer una infección por arbovirus, asociado con el rápido aumento de las especies de culícidos después de las tormentas, podría representar una mayor amenaza para la salud pública que la malaria (aunque se necesitaría más investigación y una vigilancia activa de las enfermedades para validar esta hipótesis).

Insectos vectores; control de mosquitos; control de vectores; malaria; tormenta tropical; Belice. 